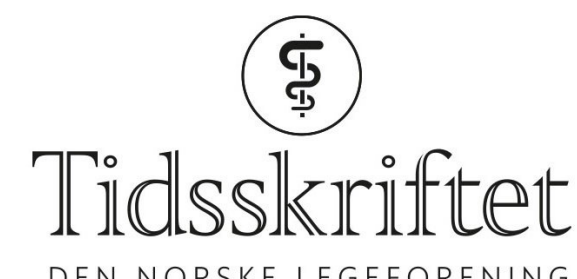

DEN NORSKE LEGEFORENING

\title{
Intensivbehandling av eldre
}

DOKTORAVHANDLINGER

FINN HUS $\varnothing$ Y ANDERSEN

E-post: fhander@gmail.com

Intensivpasientar over 80 år som er i live eitt år etter utskriving, klarar seg godt samanlikna med normalbefolkninga.

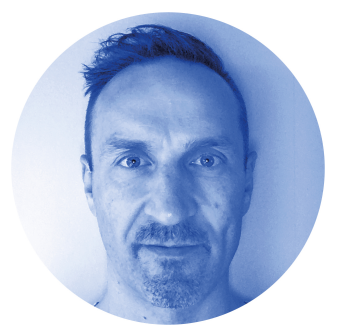

Foto: Finn H. Andersen

Talet på eldre kjem til å auke dei komande åra. Samtidig kjem nok ikkje ressursane til intensivbehandling til å auke like mykje. Dette kan føre til at eldre vert lågare prioriterte når det gjeld kven som skal få tilbod om intensivbehandling.

I min første studie, ved seks sjukehus, fann eg at kring $30 \%$ av eldre aktuelle pasientar ikkje fekk intensivbehandling, oftast grunna høg alder og dårleg funksjonsstatus.

Overlevingsanalyse etter meir enn eitt år viste at dei som fekk intensivbehandling, hadde høgare overleving enn dei avviste pasientane som vart vurdert til å vere "for sjuke/gamle».

I min andre studie, med data frå Norsk intensivregister (2006-09), fann eg at pasientar $\geq 80$ år fekk mindre intensivbehandling (liggetider, respirasjonsstøtte og pleieressursar) enn pasientar i aldersgruppa 50-8o år, sjølv om dei var like sjuke.

I min tredje studie, av intensivpasientar $\geq 80$ år innlagde ved Haukeland universitetssjukehus (2000-12), fann eg at 42 \% var i live etter eitt år, og at den vidare overlevingsraten per år var lik raten i normalbefolkninga. Livskvaliteten til dei som var i live meir enn eitt år etter, var den same som i ei alders- og kjønnsjustert kontrollgruppe.

Eldre kan dra nytte av intensivbehandling, men det kan vere vanskeleg å finne dei som har slik nytte.

\section{Disputas}

Finn Husøy Andersen disputerte for ph.d.-graden ved Norges teknisk-naturvitenskapelige universitet 8.6.2017. Tittelen på avhandlingen er Intensive care for the very old - ICU admission 
triage and outcomes.

Publisert: 12. desember 2017. Tidsskr Nor Legeforen. DOI: 10.4045/tidsskr.17.0896

(C) Tidsskrift for Den norske legeforening 2020. Lastet ned fra tidsskriftet.no 